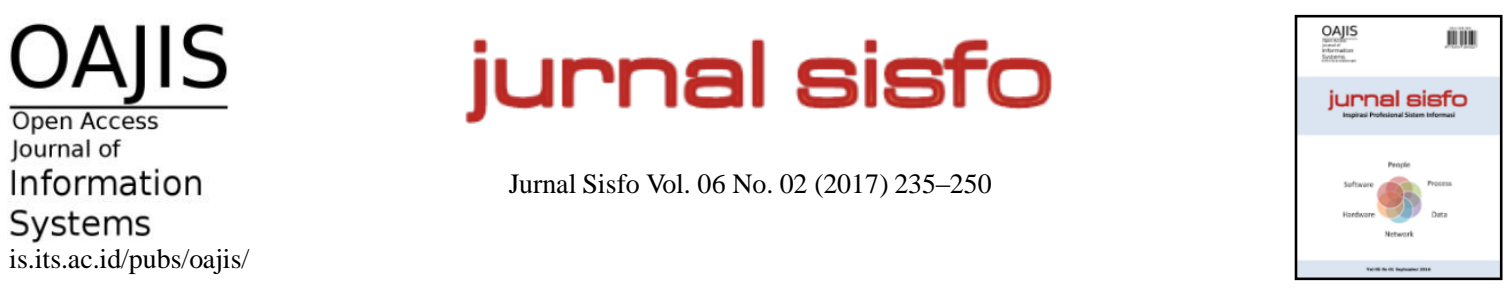

\title{
Arsitektur Microservice untuk Resiliensi Sistem Informasi
}

\author{
Hatma Suryotrisongko* \\ Jurusan Sistem Informasi, Fakultas Teknologi Informasi, Institut Teknologi Sepuluh Nopember
}

\begin{abstract}
Resilient means be able to adapt to changes and errors/damage to the systems/infrastructure. In the study of information systems, resilience is often seen as nonfunctional requirements that can be seen from the element of scalability, reliability, maintainability and availability. This study continue the previous studies, namely the development of Open Source software for the management of associations / memberships. The software has been used in AISINDO member management system (Professional Association of Information Systems Indonesia). Continuation of the research study in the form of modeling and manufacturing of proof of concept of a distributed software architecture modifications, based MICROSERVICE and Docker-container, for Resilient Information Systems. The software research last year was refactored (rewriting program code), using a new software architecture models generated in this study. The test results on a system that has been made, indicating that the system with the proposed architecture has shown improvement in the quality aspects of resilience, eg when multiple nodes servive impaired, the system can still function properly. The contribution of this study was: MICROSERVICE implementation of management systems case study associations / memberships and, and then evaluate the model after the completion of construction project software refactoring into a system based microservices.
\end{abstract}

Keywords: Microservice Architecture, Docker, Software Refactoring, Software Quality, Resiliency

\begin{abstract}
Abstrak
Resilien berarti tahan/mampu beradaptasi terhadap perubahan maupun kesalahan/kerusakan infrastruktur. Pada penelitian sistem informasi, resilience sering dilihat sebagai nonfunctional requirements yang dapat dilihat dari unsur scalability, reliability, maintainability dan availability. Penelitian ini melanjutkan hasil penelitian sebelumnya, yaitu pengembangan software Open Source untuk manajemen asosiasi/keanggotaan, dengan tujuan untuk meningkatkan kualitas software pada aspek resiliensi nya. Software tersebut saat ini telah dipakai pada sistem manajemen anggota AISINDO (Asosiasi Profesi Sistem Informasi Indonesia). Lanjutan dari penelitian-penelitian tersebut berupa penyusunan model dan pembuatan proof of concept dari modifikasi arsitektur software yang terdistribusi, berbasis microservice dan Docker-container, untuk Resilient Information Systems. Dilakukan refactoring (penulisan ulang kode program) dari software hasil penelitian sebelumnya, dengan menggunakan model arsitektur software baru yang dihasilkan di penelitian ini. Hasil pengujian pada sistem yang telah dibuat, menunjukkan bahwa sistem dengan arsitektur yang diusulkan telah menunjukkan peningkatan kualitas pada aspek resiliensi, misalkan ketika beberapa node servive mengalami gangguan, sistem dapat tetap berjalan sebagaimana mestinya. Kontribusi penelitian ini yaitu implementasi microservice untuk studi kasus sistem manajemen asosiasi/keanggotaan, lalu mengevaluasi model tersebut setelah selesai pengerjaan refactoring software menjadi sistem yang berbasis microservices.
\end{abstract}

Kata kunci: Microservice Arsitektur, Docker, Software Refactoring, Kualitas Software, Resiliensi

(c) 2017 Jurnal SISFO.

Histori Artikel : Disubmit 2 Desember 2017; Diterima 9 Januari 2017; Tersedia online 26 Januari 2017

${ }^{*}$ Corresponding Author

Email address: suryotrisongko@gmail.com (Hatma Suryotrisongko) 


\section{Pendahuluan}

Di masa lalu, menjadi responsif dalam kasus gangguan yang tidak terencana sangat menyulitkan manajemen. Untuk IT, hal tersebut bahkan lebih menantang: Sistem yang dikembangkan dirancang hanya untuk memenuhi sifat yang telah ditetapkan, dan hanya menawarkan satu set fungsionalitas terprogram untuk penanganan eksepsi. Resilience meliputi reaksi atas gangguan di luar lingkup yang sudah dikenal sebelumnya. Software/sistem informasi dianggap resilient jika memiliki kemampuan menyesuaikan kebutuhan baru yang belum eksplisit ada di dalam desain IT sebelumnya [1]. Penelitian mengenai resilience pada bidang sistem informasi telah banyak dibicarakan semenjak tahun 2010, seperti pada Enterprise Information Systems journal Volume 4, Issue 2, 2010 yang membahas topik khusus mengenai Resilient Enterprise Information Systems, yaitu bagaimana sistem informasi yang digunakan pada organisasi besar (enterprise) seperti ERP, SCM, CRM, dll dapat dirancang untuk cukup resilient [2]. Pada salah satu paper di jurnal itu, dibahas beberapa desain arsitektur software \& sistem informasi yang mampu meningkatkan performa resiliency pada sistem IT di organisasi [3].

Penelitian dan teknologi terus semakin cepat perkembangannya. Akhir-akhir ini, muncul tren baru dikalangan peneliti/praktisi Software Architect, yaitu microservices, dimana software/sistem informasi dirancang untuk terdistribusi dan memberikan layanan spesifik dan terfokus. Walaupun istilah microservices telah mulai diperkenalkan sejak tahun 2011 [4], namun pola desain arsitektur software/sistem informasi ini menjadi semakin banyak diteliti dan digunakan industri setelah munculnya teknologi container-based virtualization, yaitu Docker di akhir tahun 2014 [5]. Penelitian ini melanjutkan hasil penelitian sebelumnya, yaitu pengembangan software Open Source untuk manajemen asosiasi/keanggotaan, dengan tujuan untuk meningkatkan kualitas software pada aspek resiliensi-nya. Software tersebut saat ini telah dipakai pada sistem manajemen anggota AISINDO (Asosiasi Profesi Sistem Informasi Indonesia) dan juga telah dipublikasikan di Wordpress Plugin repository sehingga masyarakat internasional bisa turut menggunakan kode program ini. Setelah software tersebut diimplementasikan, hasil evaluasi menunjukkan kurangnya kapasitas sistem yang sudah ada dalam melayani jumlah member yang terus meningkat, sehingga perlunya peningkatan kinerja sistem dengan mencoba menerapkan pendekatan baru.

Pada paper ini, dipaparkan hasil penelitian berupa penyusunan model dan pembuatan proof of concept dari modifikasi arsitektur software yang terdistribusi, berbasis microservice dan Docker-container, untuk Resilient Information Systems. Kode program yang baru tersebut diimplementasikan pada AISINDO (Asosiasi Profesi Sistem Informasi Indonesia) sehingga bisa mendapatkan data empiris untuk evaluasi dan perbaikan model di penelitian berikutnya.

\section{Tinjauan Pustaka/Penelitian Sebelumnya}

\subsection{Resilient Information Sytems}

Resilience engineering adalah salah satu topik penelitian multi disipliner yang melibatkan banyak peneliti dari disiplin ilmu computer science, mechanical engineering, industrial engineering, dan lain-lain. Literature review terkini tentang topik ini bisa dilihat pada [6]. Perbandingan definisi resilience dapat dilihat di Tabel 1.

\subsection{Microservices}

Ada banyak solusi yang diusulkan oleh para peneliti untuk dapat meningkatkan kualitas software/sistem informasi dari sisi nonfunctional requirements (scalability, reliability, maintainability dan availability). Mulai dari penggunaan teknik mirrorring/DRC/cloud/sampai dengan pendekatan algoritma untuk dapat mengembalikan performa sistem setelah terjadi serangan [7]. 
Tabel 1. Definisi resilience dari perspektif berbagai disiplin bidang ilmu

\begin{tabular}{|c|c|}
\hline Konteks & Definisi \\
\hline Physical systems & $\begin{array}{l}\text { Kecepatan di mana sistem kembali ke tingkat keseimbangan setelah } \\
\text { perpindahan, terlepas dari osilasi menunjukkan elastisitas (ketahanan) } \\
\text { [8] }\end{array}$ \\
\hline Ecological systems & $\begin{array}{l}\text { Ukuran kegigihan sistem dan kemampuan untuk menyerap perubahan } \\
\text { dan gangguan dan tetap menjaga hubungan yang sama antara variabel } \\
\text { [9] }\end{array}$ \\
\hline Ecological systems & $\begin{array}{l}\text { Kapasitas sistem untuk menyerap gangguan dan mereorganisasi saat } \\
\text { menjalani perubahan sementara tetap mempertahankan fungsi yang } \\
\text { sama, struktur, identitas dan umpan balik [10] }\end{array}$ \\
\hline Ecological systems & $\begin{array}{l}\text { Besarnya gangguan sistem dapat menyerap sebelum strukturnya } \\
\text { didefinisikan ulang dengan mengubah variabel dan proses yang } \\
\text { mengendalikan perilaku [11] }\end{array}$ \\
\hline Ecological systems & $\begin{array}{l}\text { Kecepatan di mana sistem kembali ke titik ekuilibrium setelah terjadi } \\
\text { gangguan [12] }\end{array}$ \\
\hline $\begin{array}{l}\text { Socio-ecological } \\
\text { systems }\end{array}$ & $\begin{array}{l}\text { Kemampuan untuk mempertahankan fungsi sistem ketika terganggu } \\
\text { atau kemampuan untuk mempertahankan elemen yang dibutuhkan untuk } \\
\text { memperbaharui atau mereorganisasi jika gangguan mengubah struktur } \\
\text { fungsi sistem [10] }\end{array}$ \\
\hline $\begin{array}{l}\text { Socio-ecological } \\
\text { systems }\end{array}$ & $\begin{array}{l}\text { Besarnya gangguan yang sistem dapat mentolerir sebelum transisi } \\
\text { menjadi kondisi yang berbeda yang dikendalikan oleh satu set yang } \\
\text { berbeda dari proses [13] }\end{array}$ \\
\hline Psychology & Kapasitas untuk pulih dari keterpurukan [14] \\
\hline $\begin{array}{l}\text { Disaster } \\
\text { management }\end{array}$ & $\begin{array}{l}\text { Kemampuan unit sosial untuk mengurangi bahaya, mengandung efek } \\
\text { bencana ketika mereka terjadi dan melaksanakan kegiatan pemulihan } \\
\text { yang meminimalkan gangguan sosial dan mengurangi dampak dari } \\
\text { gempa bumi di masa depan [15] }\end{array}$ \\
\hline $\begin{array}{l}\text { Disaster } \\
\text { management }\end{array}$ & $\begin{array}{l}\text { Ketahanan menggambarkan proses aktif meluruskan diri, belajar dan } \\
\text { pertumbuhan. Konsep ini berkaitan dengan kemampuan untuk berfungsi } \\
\text { pada tingkat psikologis yang lebih tinggi dan pengalaman sebelumnya } \\
{[16]}\end{array}$ \\
\hline Individual & $\begin{array}{l}\text { Individu tangguh memiliki tiga karakteristik umum. Ini termasuk } \\
\text { penerimaan realitas, keyakinan yang kuat bahwa hidup adalah bermakna } \\
\text { dan kemampuan untuk berimprovisasi [17] }\end{array}$ \\
\hline Organisational & $\begin{array}{l}\text { Ketahanan mengacu pada kapasitas untuk rekonstruksi terus menerus } \\
\text { [18] }\end{array}$ \\
\hline Organisational & $\begin{array}{l}\text { Ketahanan adalah kualitas mendasar untuk merespon secara produktif } \\
\text { untuk perubahan signifikan yang mengganggu pola yang diharapkan } \\
\text { dari acara tanpa memperkenalkan jangka perilaku regresif [19] }\end{array}$ \\
\hline
\end{tabular}

Microservice yang belum lama ini mulai populer di kalangan praktisi Software Engineering menawarkan pendekatan yang sedikit berbeda. Sistem Informasi enterprise yang pada umumnya dibangun dengan pendekatan monolitik (aplikasi terbungkus dalam satu package besar, dimana perubahan pada salah satu bagian kode program akan besar pengaruhnya terhadap kode program yang lainnya) digeser menjadi pendekatan terdisitribusi. Aplikasi dibagi menjadi bagian-bagian kecil yang berfungsi spesifik (high cohesion) dan tidak bergantung pada komponen program lainnya (loose coupling), dengan antarmuka API (Application Programming Interface) [20]. 
Dari sudut pandang paradigma microservices, sebuah konsep kunci dalam resilient engineering adalah penyekatan. Jika salah satu komponen dari sistem gagal, kegagalan tersebut tidak akan cascade / memberikan pengaruh ke kinerja komponen yang lain. Dengan demikian, masalah dapat terisolasi dan sisanya dari komponen-komponen sistem yang lain dapat terus bekerja. Dalam sistem monolitik, jika sebuah layanan gagal, maka semuanya berhenti bekerja. Sistem dapat dijalankan pada beberapa mesin yang redundan untuk mengurangi kesempatan kegagalan/system failure. Sebaliknya, dengan microservices dapat dibangun sistem yang bisa menangani kegagalan total layanan karena layanan fungsionalitas sistem telah tersekat dalam batas yang jelas [21].

Konsep microservices ini sedikit banyak berbeda dengan paradigma pendahulunya, yaitu System Oriented Architecture (SOA). Mulai dari penggunaan protokol komunikasi pesan yang lebih ringkas (REST, dll) dibandingkan dengan SOA yang banyak menggunakan XML SOAP, sampai dengan proses desain dan pembagian fungsional yang mengedepankan pembagian berdasarkan domain fungsionalitas pada organisasi [22].

\subsection{Docker (Container)}

Docker adalah metode yang relatif baru untuk virtualisasi, yang tersedia native untuk 64-bit Linux. Dibandingkan dengan teknik virtualisasi yang lebih tradisional (seperti VMWare), Docker lebih ringan pada sumber daya sistem, dan menawarkan sistem yang hampur serupa dengan git seperti commit dan tag, dan dapat digunakan pada laptop anda maupun pada infrastruktur cloud [23].

Banyak keuntungan yang ditawarkan pada pendekatan kontainer yang ditawarkan oleh Docker, seperti memudahkan developer aplikasi untuk bebas dari permasalahan konfigurasi environment. Ketika tahap development, developer dapat menggunakan Docker untuk menciptakan environment untuk target sistem tujuan deployment aplikasi. Image dari docker tersebut dapat dengan mudah di share kepada developer lain pada tim pengembang, untuk bisa bekerja pada environment yang serupa. Ketika proses pengembangan kode program selesai, dan software siap di deploy di server / cloud, image docker tersebut bisa dengan mudah di deploy di server, sehingga permasalahan setting konfigurasi server menjadi bukan permasalahan lagi [24].

Beberapa penelitian yang mengevaluasi performa Docker dibandingkan sistem sejenis (OpenStack, virtualisasi KVM dll) menyimpulkan bahwa Docker memberikan performa yang superior, dengan ukuran size image yang kecil dan ringan tidak membebani performa server [25] 26] [27] [28].

Salah satu kasus penggunaan terbesar dan terkuat untuk penerapan kontainer (Docker) adalah microservices. Microservices adalah cara mengembangkan dan menyusun sistem perangkat lunak seperti mereka dibangun dari komponen independen kecil yang berinteraksi satu sama lain melalui jaringan. Hal ini berbeda dengan cara monolitik tradisional mengembangkan perangkat lunak, di mana ada program tunggal yang besar, misal program yang ditulis dalam bahasa pemrograman $\mathrm{C}++$ atau Java. Ketika datang kebutuhan untuk meningkatkan performa pada sistem monolit, umumnya satu-satunya pilihan adalah untuk meningkatkan keatas (scale up), di mana permintaan tambahan ditangani dengan menggunakan mesin yang lebih besar dengan lebih banyak RAM dan power CPU. Sebaliknya, microservices dirancang untuk skala keluar (scale out), di mana permintaan tambahan performa dapat ditangani oleh penyediaan beberapa tambahan mesin virtual untuk menyebar beban kerja sistem.

Dalam hal kompleksitas, microservices bagaikan pedang bermata dua. Pada sistem yang terdiri dari puluhan atau ratusan layanan microservices, kompleksitas keseluruhan sistem menjadi meningkat karena semakin rumitnya interaksi antara komponen individu. Dibandingkan dengan VMS, kontainer jauh lebih kecil dan lebih cepat untuk deployment, yang memungkinkan arsitektur MICROSERVICE menggunakan sumber daya minimal dan bereaksi dengan cepat terhadap perubahan permintaan [29]. 


\subsection{Studi Hasil Penelitian Sebelumnya (State of the Art)}

Kontribusi penelitian pada penelitian ini adalah implementasi microservice untuk studi kasus sistem manajemen asosiasi/keanggotaan. Untuk bisa menjelaskan kontribusi di atas dan posisi dari rencana penelitian ini, berikut ini di paparkan state of the art penelitian 5 tahun terakhir mengenai Microservices.

\subsubsection{Design dan Pengembangan Sistem Microservices}

[30] memilih microservices sebagai paradigma arsitektur dari sistem tracking dan manajemen armada/logistik, agar dapat meniru layanan granular untuk meningkatkan skalabilitas, dan dengan mudah mengganti layanan usang. Dilaporkan terjadinya peningkatan efisiensi operasional dan kualitas kode program karena dimemungkinkan untuk menyebarkan dengan cepat layanan baru. Microservice juga telah diterapkan untuk mengembangkan sistem Internet of Things / Mobile, seperti yang dilaporkan pada [31] dan juga [32]. Dengan menggunakan studi kasus pada aplikasi e-commerce, [15] melaporkan meningkatkan positif pada aspek scalabilitas dari sistem e-commerce yang berbasis microservices tersebut. Implementasi microservice pada smart-grid untuk metering penggunaan listrik, dilaporkan pada paper [33]. Dari paparan diatas, dapat dilihat belum adanya laporan penelitian untuk implementasi microservice pada studi kasus software manajemen asosiasi/keanggotaan.

\subsubsection{Migrasi/Refactoring Monolitik Sistem Menjadi Sistem yang Berbasis Microservices}

Referensi penelitian terkini yang paling relevan dengan rencana penelitian ini adalah pada [34]. Dimana berdasarkan pengalaman melakukan migrasi sistem ke microservice, para peneliti di paper tersebut menyarankan sebuah metode untuk migrasi dari sistem berbasis monolitik menjadi sistem berbasis microservices melalui 15 langkah (Microservices Migration Patterns). Penelitian ini mencoba mengadopsi metode migrasi yang diusulkan [34], dan mengevaluasinya setelah selesai pengerjaan project refactoring software asosiasi/manajemen keanggotaan menjadi sistem yang berbasis microservices.

Langkah-langkah dari Microservices Migration Patterns adalah

1. Enable the Continuous Integration

2. Recover the Current Architecture

3. Decompose the Monolith

4. Decompose the Monolith Based on Data Ownership

5. Change Code Dependency to Service Call

6. Introduce Service Discovery

7. Introduce Service Discovery Client

8. Introduce Internal Load Balancer

9. Introduce External Load Balancer

10. Introduce Circuit Breaker

11. Introduce Configuration Server

12. Introduce Edge Server

13. Containerize the Services

14. Deploy into a Cluster and Orchestrate Containers

15. Monitor the System and Provide Feedback

\subsubsection{Semantic}

[35] mengembangkan sistem bernama Synapse, sistem berbasis semantik untuk data-driven fitur pada web, seperti targeting customer, recommendations, atau predictions. Puluhan microservices di-deploy untuk melayani 450.000 users. Teknologi semantik juga diterapkan pada penelitian [36] untuk memungkinkan adanya kolaborasi penggunaan microservices dengan organisasi luar. Dengan teknologi 
semantik, dibuatlah ekosistem dimana seluruh microservices berkolaborasi menjadi sebuah unit yang tunggal.

\subsubsection{Testing}

[1] melakukan benchmark untuk mengukur performa sistem microservice yang dibangun dengan dua jenis arsitektur menggunakan container, yaitu: master-slave, atau nested-container. Pada paper [37], juga dilaporkan hasil pengukuran performa sistem microservice, namun dari sisi pengaruhnya terhadap network traffic. [38] mengusulkan reusable automated acceptance testing architecture, untuk pengujian/mengukur penerimaan pengguna (user acceptance) pada project yang dikembangkan menggunakan microservice dengan Behavior-Driven Development (BDD) agile software development processes. Di sisi lain, validasi microservice menjadi sorotan pada penelitian [39] dan [40]. Pada paper tersebut, diusulkan methodologi validasi untuk sistem microservice, dimana diperlukan validasi yang komprehesif untuk individual microservices dan komunikasinya dengan microservices lain. Pentingnya testing untuk menguji kualitas sistem juga turut menjadi fokus di [41], dimana dibahas penerapan Learning-based testing (LBT) untuk secara otomatis men-generate test cases untuk blackbox testing.

\subsubsection{Resilient / Failure}

Docker juga digunakan pada [40] untuk memecahkan masalah service discovery pada microservice. Serf node adalah Docker image yang bisa di-deploy ke dalam cluster, dimana dia kemudian menyediakan mekanisme service discovery, monitoring, dan self-healing. [42] juga turut membahas mengenai selfhealing pada microservice, dimana sistem mampu mengelola dirinya sendiri supaya mampu beradaptasi terkait adanya lonjakan traffic/request maupun kegagalan/failure pada microservice.

\subsubsection{Service Deployment/Discovery}

Karena filosofi tersebar/terdistribusi pada microservice menimbulkan tantangan pada koordinasi/discovery layanan, peneliti dari University of Prince Edward Island [43] melaporkan penggunaan Traverna (open source domain-independent Workflow Management System) pada project yang mereka kerjakan. Pada sisi lain, [44] berusaha untuk memecahkan permasalahan yang sering timbul pada sistem microservice, yaitu pada konfigurasi deployment. Pada paper tersebut, diusulkan sebuah tool bernama JRO (Jolie Redeployment Optimiser), untuk otomasi dan optimasi deployment pada microservices. Workflow microservice yang menggunakan tool JRO tersebut dilaporkan di [45].

\subsubsection{Business Process Modelling (BPM)}

[46] mengusulkan compiler architecture untuk memodelkan dan mengeksekusi proses bisnis, sebagai sebuah rangkaian microservices yang saling berhubungan.

\subsubsection{Security}

Microservices sebagai sebuah arsitektur sistem yang terdistribusi menimbulkan resiko munculnya celah keamanan, pada komunikasi antar microservices. [47] mengusulkan sebuah security-as-a-service untuk aplikasi berbasis microservices. dengan menambahkan sebuah API pada network hypervisor, memungkinkan untuk adanya flexible monitoring dan policy enforcement infrastructure untuk mengamankan network traffic pada sistem antar microservices.

\section{Metodologi}




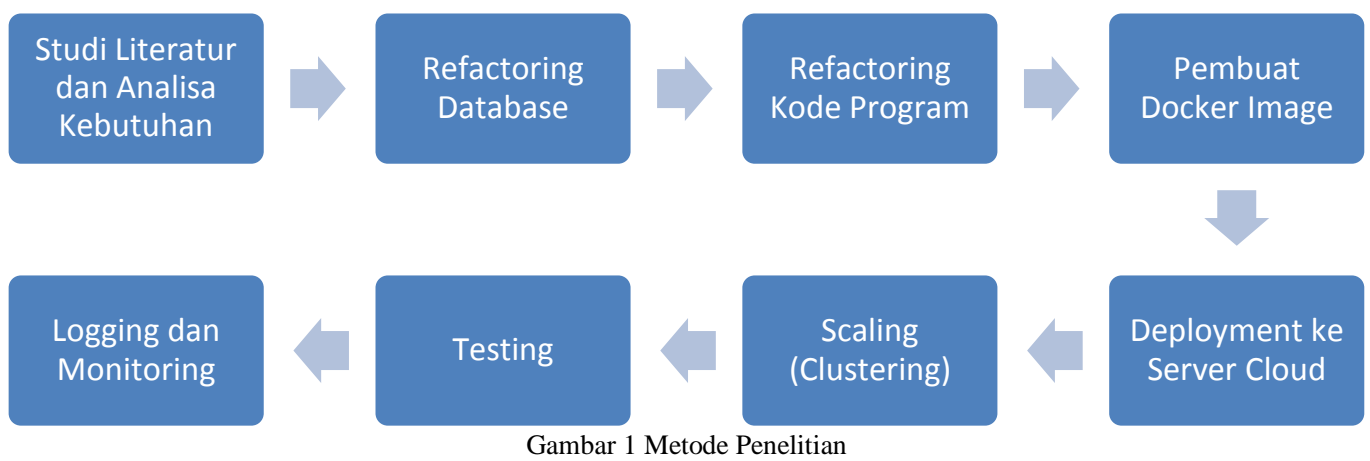

\subsection{Studi Literatur dan Analisa Kebutuhan}

Gambar 1 menunjukkan alur metodologi penelitian ini. Pertama-tama dilakukan studi literatur, membaca referensi dan paper terkait Microservice / Docker Container untuk mematangkan pemahaman terhadap permasalahan yang akan dihadapi.

\subsection{Refactoring Database}

Sebelum mulai menulis ulang kode program, database AISINDO yang ada saat ini (Gambar 2) di-refactor, untuk disesuaikan dengan rencana pengembangan menjadi sistem yang terdistribusi. Hal ini akan dilakukan dengan menjalankan tiga langkah, sesuai metode refaktoring database yang dijelaskan pada [34], yaitu :

1. Breaking Foreign Key Relationships: memisahkan ketergantungan antar tabel, karena nantinya foreign key look up diganti menjadi pemanggilan API (Application Programming Interface) pada tabel yang dituju pada Gambar 2.

2. Shared Static Data: serupa dengan langkah sebelumnya, data statis yang di-share antar tabel akan diganti menjadi API call.

3. Shared Tables: pada kondisi dimana satu tabel diakses oleh beberapa domain bisnis, maka tabel perlu dipecah menjadi dua atau lebih sesuai dengan pengaturan domain kepemilikan data.

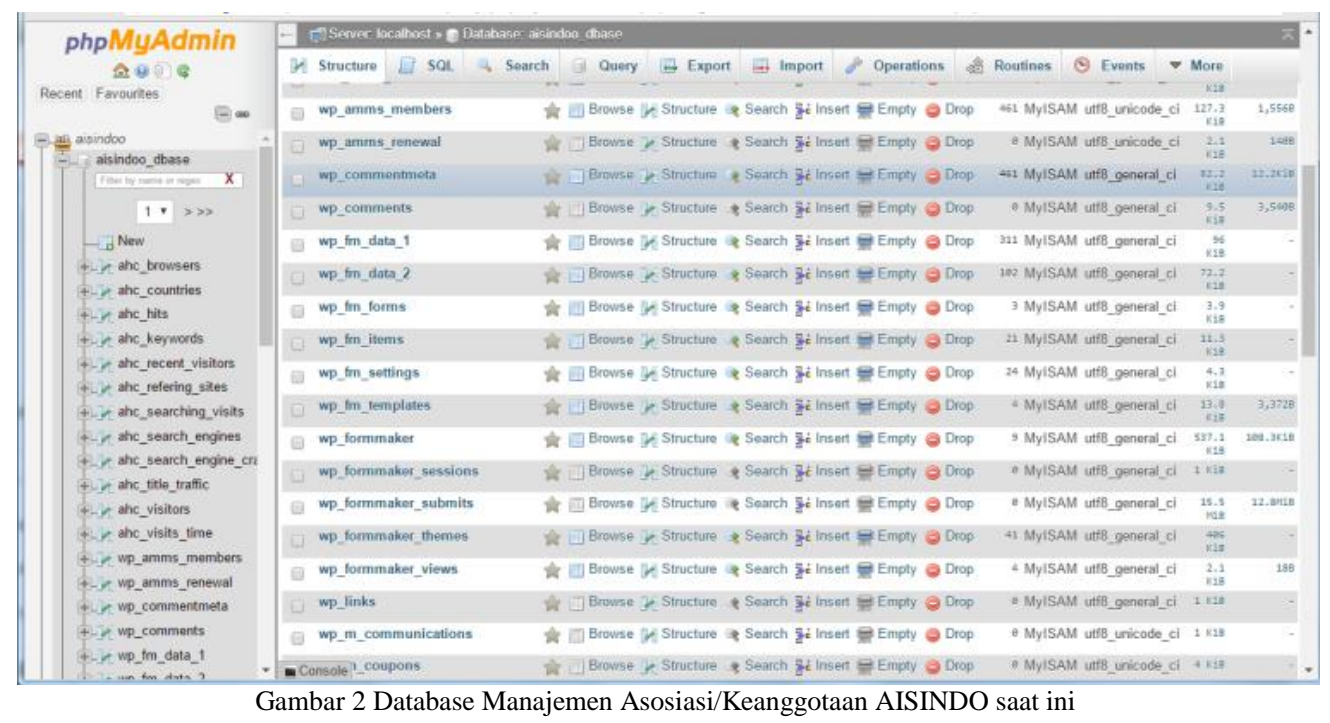




\subsection{Refactoring Kode Proggram}

Kode program akan di-refactor, dipecah berdasarkan domain fungsionalitas bisnisnya, sesuai metode refaktoring database yang dijelaskan pada [34]. Kode program ditulis menggunakan bahasa pemrograman Java EE. Pola integrasi yang akan digunakan adalah menggunakan REST Asynchronous, namun pada kondisi dimana diperlukan adanya transaksi (ACID) maka akan menggunakan Java Transaction API (JTA).

\subsection{Pembuat Docker Image}

Docker image berbasis Fedora 21, application Server Wildfly 7 dan database Apache Cassandra akan digunakan untuk image container aplikasi microservice yang akan digunakan (lihat Gambar 3).

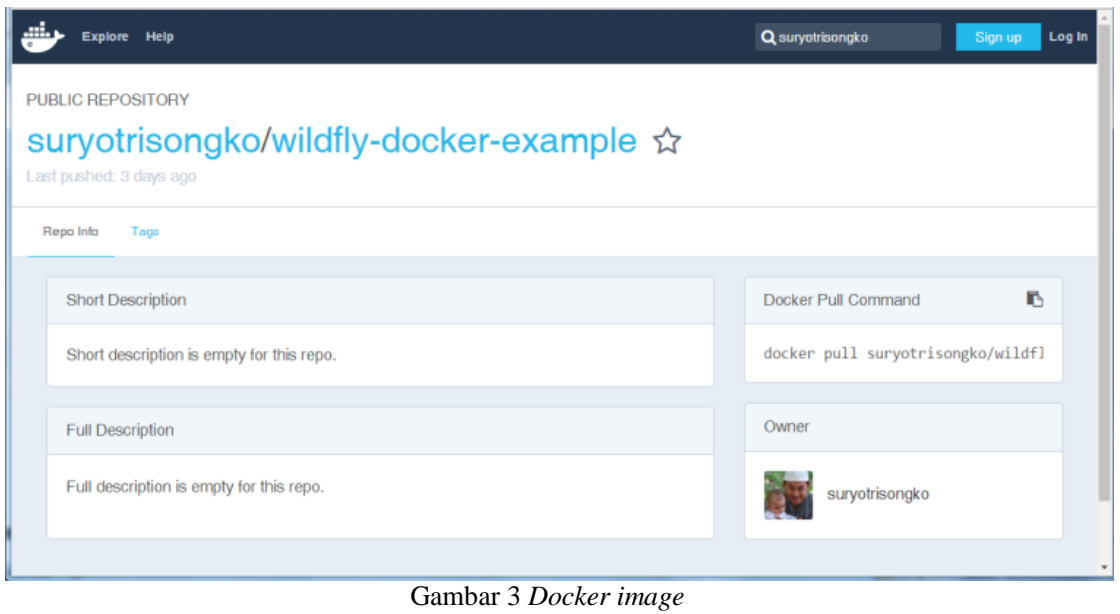

\subsection{Deployment ke Server Cloud}

Deployment container Docker yang telah dikembangkan direncakan di layanan Google App Engine atau layanan cloud yang lain, misal Amazon AWS (Gambar 4).

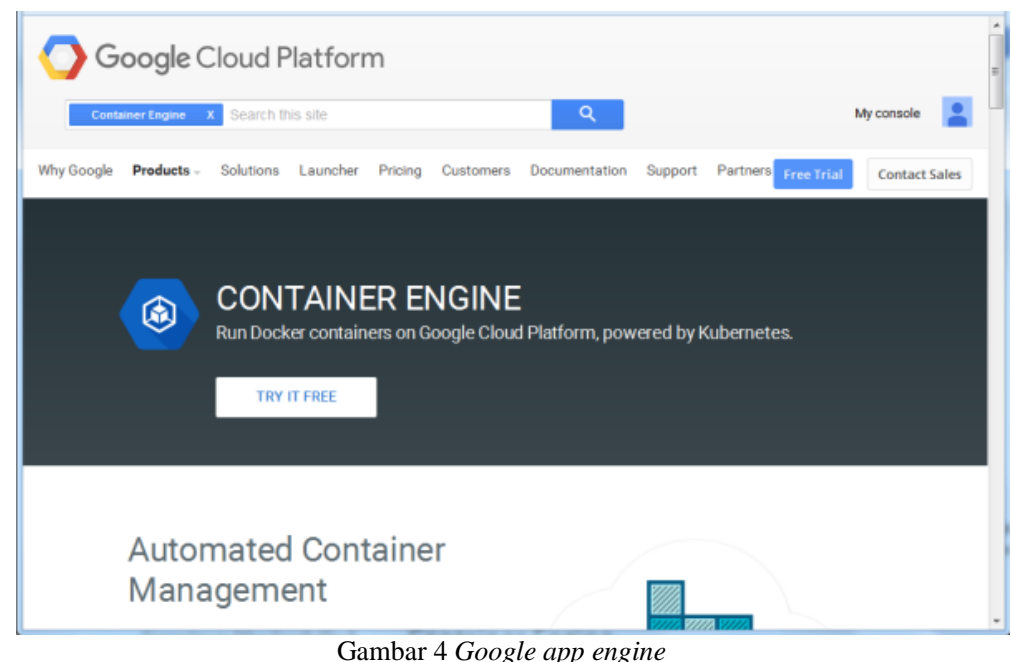




\subsection{Scaling (Clustering)}

Clustering docker container akan menggunakan teknologi Docker Swarm. Arsitektur dasar Swarm cukup mudah dimana masing-masing host menjalankan agen Swarm dan satu host menjalankan manajer Swarm (cluster tes kecil host ini juga dapat menjalankan agen). Manajer bertanggung jawab untuk orkestrasi dan penjadwalan kontainer pada host.

\subsection{Testing}

Tiga macam pengujian akan dilakukan pada sistem microservices yang sudah dikembangkan yaitu:

1. Unit test: Setiap service harus memiliki seperangkat unit test yang terkait. Unit test harus menguji potongan kecil dan terisolasi dari fungsi.

2. Component tests : Ini dapat pada tingkat pengujian antarmuka eksternal dari layanan individual, atau pada tingkat pengujian subsistem dari kelompok service. Pengujian ini juga penting untuk mengekspos metrik dan logging melalui layanan API pada saat pengujian.

3. End-to-end test : Tes yang memastikan seluruh sistem bekerja. Semua fungsionalitas bisnis yang dirancang diuji kinerjanya.

\subsection{Logging dan Monitoring}

Untuk logging dan monitoring sistem, ELK stack (Elasticsearch, Logstash, and Kibana) akan digunakan (lihat Gambar 5).

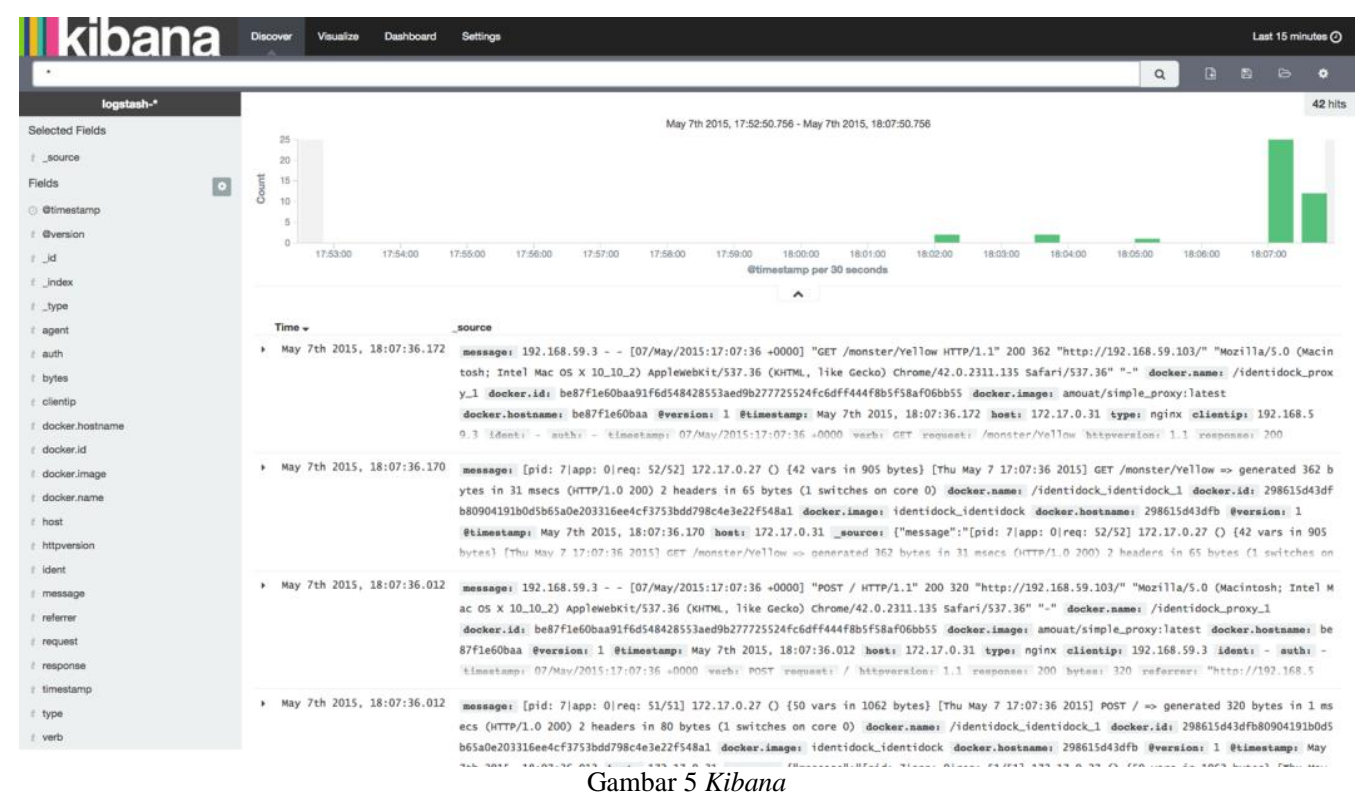

\section{Hasil dan Pembahasan}

\subsection{Studi literatur dan analisa kebutuhan}

Pertama-tama, dilakukan analisa kebutuhan yang lebih mendalam, mulai dari dengan cara mengevaluasi sistem sebelumnya (Gambar 6 dan 7), hingga wawancara dengan berbagai stakeholder AISINDO terlebih dahulu. 


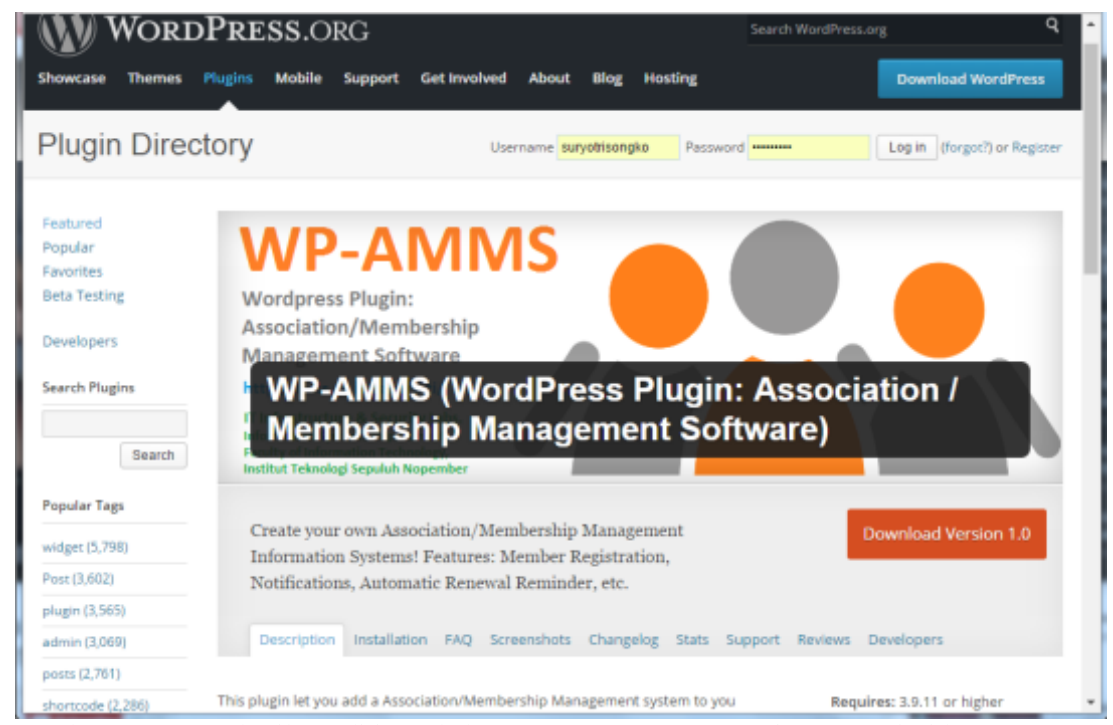

Gambar 6 Software hasil penelitian sebelumnya: Open Source manajemen asosiasi/keanggotaan



Gambar 7 Software hasil penelitian sebelumnya telah digunakan untuk manajemen anggota AISINDO (Asosiasi Profesi Sistem Informasi Indonesia)

Selain mempelajari berbagai paper "state of the art" tentang topik yang terkait, juga dilakukan telaah pada buku practical untuk persiapan teknis penulisan kode program dan database. Kemudian, untuk bisa memahami kebutuhan sistem pada AISINDO, maka dilakukan kajian analisa kebutuhan sistem, dengan cara menganalisa sistem eksisting dan juga wawancara pada stakeholder dan pemegang keputusan di organisasi AISINDO. Wawancara dan diskusi dengan stakeholder dilakukan pada even AISINDO Annual Meeting yang digelar di hotel Inna Garuda Yogyakarta, 14 Agustus 2016.

Selanjutnya, dilakukan analisa kondisi sistem eksisting, untuk memetakan Use Case kebutuhan sistem yang ada. Use Case dibagi menjadi dua bagian, yaitu Use Case untuk penggunaa tamu (pengunjung web aisindo/anggota asosiasi AISINDO) dan Use Case untuk admin sistem (direktur keanggotaan AISINDO 
dan tim). Pada masing-masing kondisi eksisting, kemudian disimpulkan kebutuhan service/layanan yang harus ada pada sistem baru.

\subsection{Refactoring Database}

Pada tahap ini, dilakukan analisa kondisi existing dan kemudian dilakukan transformasi yang diperlukan untuk menyiapkan database pada sistem baru. Pada sistem existing, database menggunakan database MySQL. Hasil dari refactoring database berupa struktur database NoSQL Cassandra, yang memiliki perbedaan cara kerja dibandingkan dengan Relational DBMS seperti dihilangkannya foreign key constraint, dan sebagainya.

\subsection{Refactoring Kode Proggram}

Kode program dikembangkan menggunakan Java Spring Boot, dengan arsitektur dapat dilihat pada Gambar 8 yang menggambarkan implementasi Arsitektur Microservice untuk Resiliensi Sistem Informasi. Gambar 8 juga menunjukkan letak dari Arsitektur Microservice yang berfungsi untuk Resiliensi Sistem Informasi, yaitu pada microservice node yang terbungkus oleh Zuul proxy sebagai Gateway sistem load balancer, dengan Eureka server dan Config server untuk memungkinkan manajemen sistem yang terpusat dan dinamis.



Keterangan :

1) Spring Cloud Config. "Spring Cloud Config" menyediakan dukungan server dan client-side untuk konfigurasi externalized dalam sistem terdistribusi. Dengan "Config Server" sistem ini memiliki tempat sentral untuk mengelola properti eksternal untuk aplikasi di semua lingkungan. Implementasi standar dari backend server penyimpanan menggunakan "git".

2) EUREKA. EUREKA untuk Service registry: Sebuah registri layanan menyediakan lingkungan runtime untuk layanan untuk secara otomatis mempublikasikan ketersediaan mereka pada saat runtime. Sebuah registri akan menjadi sumber informasi yang baik untuk memahami topologi layanan di setiap titik.

3) ZUUL Proxy. Zuul Proxy secara internal menggunakan server Eureka untuk service discovery, dan Ribbon untuk load balancing antara layanan. Proxy Zuul juga mampu melakukan routing, monitoring, mengelola ketahanan, keamanan, dan sebagainya. Secara sederhana, dapat dipertimbangkan Zuul layanan reverse proxy. Dengan Zuul, bahkan dapat diubah perilaku dari layanan mendasari dengan menimpa mereka di lapisan API. 


\subsubsection{Hasil Kode Program BackEnd}

Microservice yang berjalan pada sisi belakang (back-end) meliputi REST-Service yang dibagi menjadi dua bagian: 1) REST Service yang terbuka dan tidak memerlukan otentifikasi, dan 2) REST Service yang terproteksi oleh JWT Token Based Otentifikasi. Pola komunikasi front-end dengan back-end terjadi secara asynchronous, sehingga server tidak perlu lagi mengingat session sebagaimana seperti pola komunikasi client-server untuk aplikasi berbasis web seperti biasanya. Berikut ini daftar fungsi REST yang tersedia pada sisi back-end, dapat dilihat di Gambar 9 dan Gambar 10. Format data JSON digunakan untuk memudahkan/menghilangkan beban payload untuk melakukan parsing pesan.

\begin{tabular}{|c|c|c|c|c|}
\hline \multicolumn{2}{|c|}{ expert-controller: Expert Controller } & \multirow[t]{2}{*}{ Show/Hide } & \multirow[t]{2}{*}{ List Operations } & \multirow{2}{*}{$\begin{array}{r}\text { Expand Operations } \\
\text { getAllExperts }\end{array}$} \\
\hline GET & /expert/all & & & \\
\hline बहा & /expert/detail & & & getExpertByUserld \\
\hline Gहा & /expert/featured & & & getfeaturedExperts \\
\hline दा & /expert/search & & getExpertBykeyw & ordexpertiselocation \\
\hline \multicolumn{2}{|c|}{ pdu-resources: Pdu Resources } & Show/Hide & List Operations & Expand Operations \\
\hline \multicolumn{2}{|c|}{ photo-resource : Photo Resource } & Show/Hide & List Operations & Expand Operations \\
\hline \multicolumn{2}{|r|}{ specialization-controller : Specialization Controller } & Show/Hide & List Operations & Expand Operations \\
\hline Gहा & /specialization/all & & & getAllspecializations \\
\hline GET & /specialization/detail & & & getSpecializationByld \\
\hline \multicolumn{2}{|c|}{ user-controller : User Contiroller } & Show/Hide & List Operations & Expand Operations \\
\hline GET & /user/isactivemember & & & isactivemember \\
\hline post & /user/login & & & $\log$ in \\
\hline POST & /user/register & & & registerUser \\
\hline post & /user/resetpassword & & & resetpassword \\
\hline GET & /user/verify & & & verifyuser \\
\hline
\end{tabular}

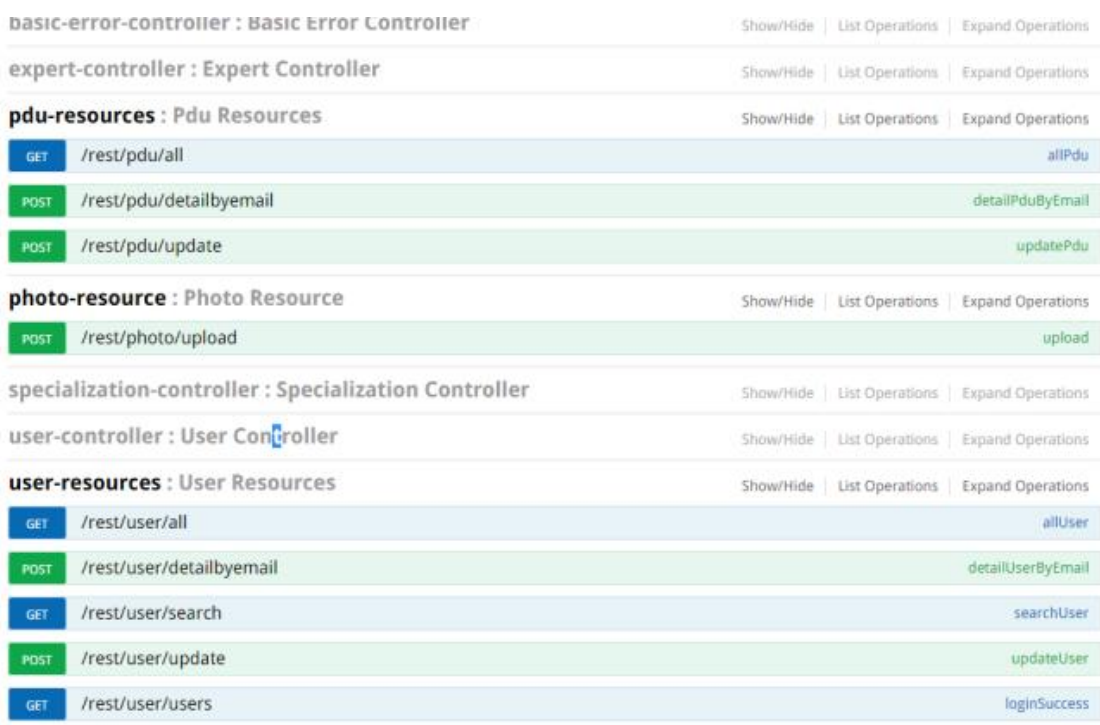

Gambar 10 REST Security dengan JWT Token Based Authentication 


\subsubsection{Hasil kode program Front End}

Kode program Front End di-develop menggunakan angular 2 typescript. Terdiri dari beberapa fasilitas utama, seperti: fitur pencarian expert, fitur featured expert, fitur registrasi membership, dan fitur klain PDU (Personal Development Unit) untuk member bisa meningkatkan level status membership-nya. Screenshot aplikasi dapat dilihat pada Gambar 11.

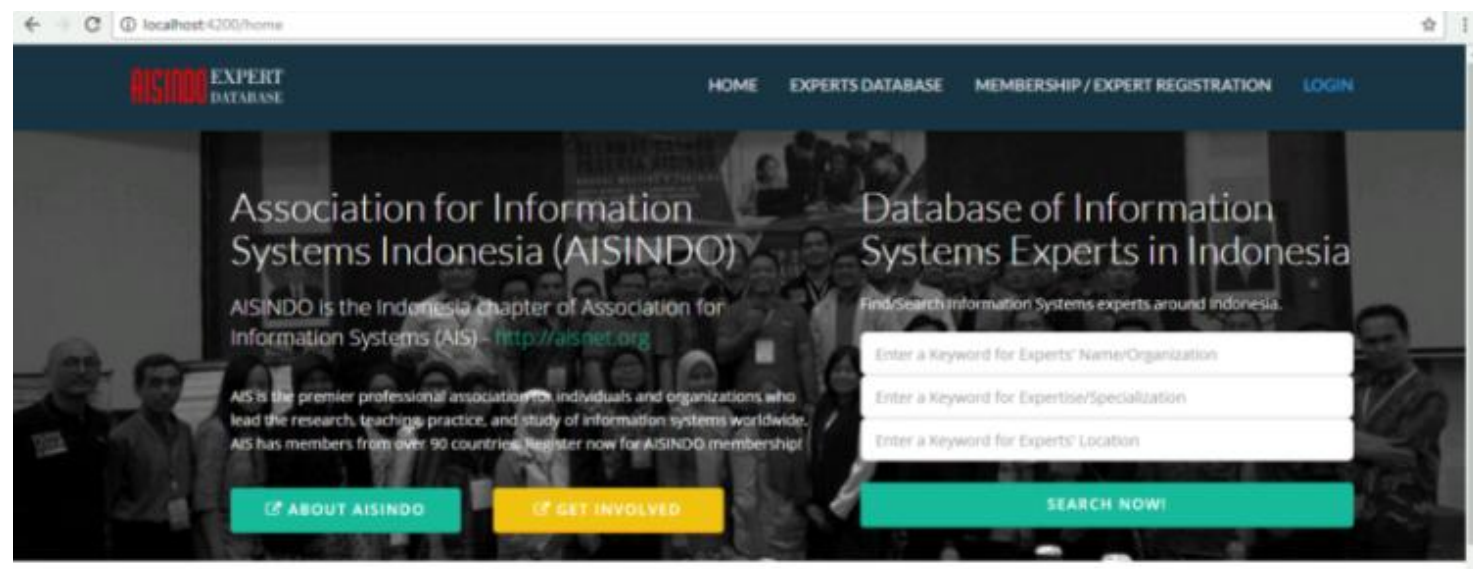

\section{Featured Experts}

Gambar 11 Front end halaman depan AISINDO Membership / Expert Database

\subsection{Pembuat Docker Image, Deployment ke Server Cloud, dan Scaling (Clustering)}

Setelah front-end dan back-end selesai dikerjakan microservices di-deploy ke server hosting akan menggunakan AWS Amazon EC2 (Gambar 12). Prototipe sistem disiapkan menggunakan lima komputer server yang sudah disiapkan di laboratorium, untuk menguji sistem secara lokal.

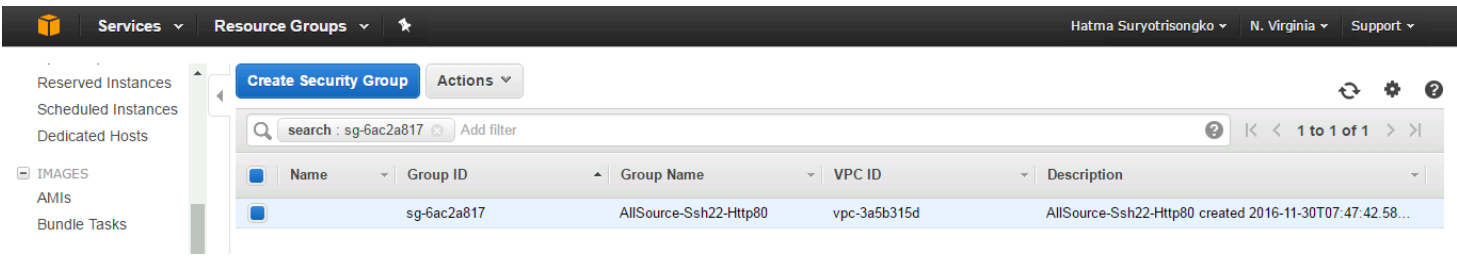

Gambar 12 Amazon AWS EC2 Instance

\subsection{Testing, Logging dan Monitoring}

Selain pengujian standar seperti Unit Testing, Component Testing dan End to End Testing, juga dilakukan pengujian untuk spesifik menguji apakah resiliensi sudah tercapai. Pengujian dilakukan untuk menguji apakah arsitektur sistem yang diusulkan pada Gambar 8 tetap dapat available ketika beberapa service node mengalami gangguan. Simulasi kegagalan/gangguan dilakukan dengan cara mensimulasikan system down/failure secara acak pada node-node microservice. Hasil dari pengujian tersebut menyimpulkan bahwa layanan microservice tetap dapat selalu tersedia, meskipun salah satu node dimatikan secara acak, selama masih ada minimum satu node microservice yang tersedia. 


\section{Kesimpulan}

\subsection{Simpulan}

Model/desain arsitektur software/sistem informasi yang telah dikembangkan menunjukan aspek kualitas resiliensi, dengan pendekatan Microservices - Docker container yang telah dikembangkan dengan sistem back-end Spring Boot dan front-end Angular2. Pola komunikasi REST Service dengan format JSON memberikan kemudahan dalam implementasi dan juga tidak membebani server.

Proof of concept dari model/desain arsitektur yang diusulkan telah dibuat, dengan menulis ulang kode program (refactoring) Software Open Source manajemen asosiasi/keanggotaan. Kode program tersebut sudah diimplementasikan pada website AISINDO (Asosiasi Profesi Sistem Informasi Indonesia) di alamat web expert.aisindo.org, sehingga untuk kelanjutan penelitian berikutnya bisa memanfaatkan data empiris untuk evaluasi dan perbaikan model di penelitian berikutnya.

Aspek reseliensi dapat diamati pada ketangguhan system ketika salah satu instance microservice mengalami gangguan. Dari sudut pandang end-user, gangguan ini tidak akan dapat dirasakan, karena backend telah ditangani oleh kombinasi antara Eureka dan Zuul proxy yang akan berfungsi sebagai load balancer untuk membagi beban sekaligus untuk menyembunyikan gangguan yang dialami oleh sistem di belakang layer. Dari hasil pengujian, dapat disimpulkan bahwa aspek kualitas resiliensi dapat dicapai pada arstiketur sistem yang diusulkan di penelitian ini.

Penelitian ini berhasil menunjukkan implementasi microservice untuk studi kasus sistem manajemen asosiasi/keanggotaan yang digunakan untuk membuktikan adopsi model Microservices Migration Patterns, lalu mengevaluasi model tersebut pada implementasi di Asosiasi Sistem Informasi Indonesia (AISINDO).

\subsection{Saran}

Untuk penelitian berikutnya, model microservice yang digunakan pada penelitian ini sebaiknya dimodifikasi dengan memanfaatkan model Hybrid Cloud. Pola model ini akan sangat cocok untuk kasus penggunaan dimana database sangat membutuhkan privacy, sebagai contoh data public pada $e$ Government di Indonesia.

\section{Pengakuan}

Penelitian ini dibiayai oleh skema Hibah Penelitian Pemula ITS 2016.

\section{Daftar Rujukan}

[1] Müller, G., Koslowski, T. G., \& Accorsi, R. (2013). Resilience - A New Research Field in Business Information Systems? In W. Abramowicz (Ed.), Business Information Systems Workshops (pp. 3-14). Springer Berlin Heidelberg. Retrieved from http://link.springer.com/chapter/10.1007/978-3-642-41687-3 2

[2] Zhang, P. W. J. (2010). Guest Editor's foreword. Enterprise Information Systems, 4(2), 95-97. http://doi.org/10.1080/17517571003770468

[3] Liu, D., Deters, R., \& Zhang, W. J. (2010). Architectural design for resilience. Enterprise Information Systems, 4(2), $137-152$. http://doi.org/10.1080/17517570903067751

[4] Microservices. (n.d.). Retrieved March 30, 2016, from http://martinfowler.com/articles/microservices.html

[5] Stubbs, J., Moreira, W., \& Dooley, R. (2015). Distributed Systems of Microservices Using Docker and Serfnode. In 2015 7th International Workshop on Science Gateways (IWSG) (pp. 34-39). http://doi.org/10.1109/IWSG.2015.16

[6] Bhamra, R., Dani, S., \& Burnard, K. (2011). Resilience: the concept, a literature review and future directions. International Journal of Production Research, 49(18), 5375-5393. http://doi.org/10.1080/00207543.2011.563826

[7] Ishida, Y. (2015). Self-Repair Networks: A Mechanism Design (Vol. 101). Springer. 
[8] Bodin, P., \& Wiman, B. (2004). Resilience and other stability concepts in ecology: Notes on their origin, validity, and usefulness. ESS Bulletin, 2(2), 33-43.

[9] Holling, C. S. (1973). Resilience and stability of ecological systems. Annual Review of Ecology and Systematics, 1-23.

[10] Walker1a, B., Carpenter, S., Anderies1b, J., Abel1b, N., Cumming, G., Janssen, M., ... Pritchard, R. (2002). Resilience management in social-ecological systems: a working hypothesis for a participatory approach. Conservation Ecology, 6(1), 14.

[11] Gunderson, L. H. (2000). Ecological resilience--in theory and application. Annual Review of Ecology and Systematics, 425439.

[12] Tilman, D., \& Downing, J. A. (1996). Biodiversity and stability in grasslands. In Ecosystem Management (pp. 3-7). Springer.

[13] Carpenter, S., Walker, B., Anderies, J. M., \& Abel, N. (2001). From metaphor to measurement: resilience of what to what? Ecosystems, 4(8), 765-781.

[14] Luthans, F., Vogelgesang, G. R., \& Lester, P. B. (2006). Developing the psychological capital of resiliency. Human Resource Development Review, 5(1), 25-44.

[15] Bruneau, M., Chang, S. E., Eguchi, R. T., Lee, G. C., O’Rourke, T. D., Reinhorn, A. M., ... von Winterfeldt, D. (2003). A framework to quantitatively assess and enhance the seismic resilience of communities. Earthquake Spectra, 19(4), 733-752.

[16] Hasselbring, W. (2016). Microservices for Scalability (Keynote Presentation).

[17] Coutu, D. L. (2002). How resilience works. Harvard Business Review, 80(5), 46-56.

[18] Hamel, G., \& Valikangas, L. (2003). The quest for resilience. Harvard Business Review, 81(9), 52-65.

[19] Hollnagel, E., Woods, D. D., \& Leveson, N. (2007). Resilience engineering: concepts and precepts. Ashgate Publishing, Ltd..

[20] Newman, S. (2015). Building Microservices. O'Reilly Media, Inc.

[21] Namiot, D., \& Sneps-Sneppe, M. (2014). On micro-services architecture. International Journal of Open Information Technologies, 2(9).

[22] Thones, J. (2015). Microservices. Software, IEEE, 32(1), 116-116.

[23] Fink, J. (2014). Docker: A software as a service, operating system-level virtualization framework. Code4Lib Journal, 25.

[24] Jiang, K., \& Song, Q. (2015). A Preliminary Investigation of Container-Based Virtualization in Information Technology Education (pp. 149-152). Presented at the Proceedings of the 16th Annual Conference on Information Technology Education, ACM.

[25] Ismail, B. I., Mostajeran Goortani, E., Ab Karim, M. B., Ming Tat, W., Setapa, S., Luke, J. Y., \& Hong Hoe, O. (2015). Evaluation of Docker as Edge computing platform (pp. 130-135). Presented at the Open Systems (ICOS), 2015 IEEE Confernece on, IEEE.

[26] Amaral, M., Polo, J., Carrera, D., Mohomed, I., Unuvar, M., \& Steinder, M. (2015). Performance Evaluation of Microservices Architectures using Containers (pp. 27-34). Presented at the Network Computing and Applications (NCA), 2015 IEEE 14th International Symposium on, IEEE.

[27] Špacek, F., Sohlich, R., \& Dulík, T. (2015). Docker as platform for assignments evaluation. Procedia Engineering, 100, 16651671.

[28] Ou, A. Y.-Z., \& Chen, J.-C. (2015). Head-to-Head: Which is the Better Cloud Platform for Early Stage Start-up? Docker versus OpenStack.

[29] Mouat, A. (2015). Using Docker: Developing and Deploying Software with Containers. " O'Reilly Media, Inc.".

[30] Schneider, T., Car, C., \& Wolfsmantel, A. (2016). Achieving Cloud Scalability with Microservices and DevOps in the Connected Car Domain. In Software Engineering (Workshops) (pp. 138-141).

[31] Bak, P., Melamed, R., Moshkovich, D., Nardi, Y., Ship, H., \& Yaeli, A. (2015). Location and Context-based Microservices for Mobile and Internet of Things Workloads (pp. 1-8). Presented at the Mobile Services (MS), 2015 IEEE International Conference on, IEEE.

[32] Familiar, B. (2015). IoT and Microservices. In Microservices, IoT, and Azure (pp. 133-163). Springer.

[33] Rodríguez Molina, J. (2015). Distribution of microservices for hardware interoperability in the Smart Grid (Doctoral dissertation, ETSIS_Telecomunicacion).

[34] Balalaie, A., Heydarnoori, A., \& Jamshidi, P. (2015). Microservices Migration Patterns.

[35] Viennot, N., Lécuyer, M., Bell, J., Geambasu, R., \& Nieh, J. (2015). Synapse: a microservices architecture for heterogeneousdatabase web applications (p. 21). Presented at the Proceedings of the Tenth European Conference on Computer Systems, ACM.

[36] Versteden, A., Pauwels, E., \& Papantoniou, A. (2015). An Ecosystem of User-facing Microservices Supported by Semantic Models. (pp. 12-21). Presented at the USEWOD-PROFILES@ ESWC.

[37] Kratzke, N. (2015). About Microservices, Containers and their Underestimated Impact on Network Performance. CLOUD COMPUTING 2015, 180.

[38] Rahman, M., \& Gao, J. (2015). A Reusable Automated Acceptance Testing Architecture for Microservices in Behavior-Driven Development (pp. 321-325). Presented at the Service-Oriented System Engineering (SOSE), 2015 IEEE Symposium on, IEEE.

[39] Savchenko, D., \& Radchenko, G. (2015). Microservices Validation: Methodology and Implementation. Presented at the CEUR Workshop Proceedings. Vol. 1513: Proceedings of the 1st Ural Workshop on Parallel, Distributed, and Cloud Computing for Young Scientists (Ural-PDC 2015).-_Yekaterinburg, 2015.

[40] Savchenko, D., Radchenko, G., \& Taipale, O. (2015). Microservices validation: Mjolnirr platform case study (pp. 235-240). Presented at the Information and Communication Technology, Electronics and Microelectronics (MIPRO), 2015 38th International Convention on, IEEE.

[41] Nycander, P. (2015). Learning-Based Testing of Microservices: An Exploratory Case Study Using LBTest.

[42] Toffetti, G., Brunner, S., Blöchlinger, M., Dudouet, F., \& Edmonds, A. (2015). An architecture for self-managing microservices (pp. 19-24). Presented at the Proceedings of the 1st International Workshop on Automated Incident Management in Cloud, ACM. 
[43] Moses, D., \& Pound, P. (2014). A Distributed Microservices Framework Integrating Taverna. Open Repositories 2014.

[44] Gabbrielli, M., Giallorenzo, S., Guidi, C., Mauro, J., \& Montesi, F. (2016). Self-Reconfiguring Microservices. In Theory and Practice of Formal Methods (pp. 194-210). Springer.

[45] Safina, L., Mazzara, M., \& Montesi, F. (2015). Data-driven Workflows for Microservices. arXiv Preprint arXiv:1511.02597.

[46] Singer, R. (2016). Business Process Modeling and Execution--A Compiler for Distributed Microservices. arXiv Preprint arXiv:1601.05976.

[47] Sun, Y., Nanda, S., \& Jaeger, T. (2015). Security-as-a-Service for Microservices-Based Cloud Applications (pp. 50-57). Presented at the 2015 IEEE 7th International Conference on Cloud Computing Technology and Science (CloudCom), IEEE. 